\title{
SZEGED KöZÖSSÉGI KÖZLEKEDÉSÉNEK JÖVŐJE ELEKTROMOS MEGHAJTÁSÚ JÁRMÜVEK HASZNÁLATÁ VAL AZ ELIPTIC PROJEKT TAPASZTALATAI ALAPJÁN
}

\author{
Tóth István Tibor - Gál József
}

\begin{abstract}
Absztrakt: Városiasodó világunkban mindig fontos feladat volt a helyi közlekedés hatékony, gazdaságos, fenntartható kialakítása, megvalósítása. A fenntarthatóság alatt napjainkban szinte mindenki a környezetbarát, energiahatékony megoldások alkalmazását érti, ami általánosan elfogadott szemléletben az egyéni közlekedést kiváltó elektromos hajtású közösségi közlekedést, kerékpározást, gyaloglást, carsharing-et és e-autózást jelent. A lakosság számával és életmódjának változásával bővülö egyéni utazások száma miatt egyre bonyolultabb olyan megoldást ajánlani, ami korunk emberének megfelel. Szegeden, a településszerkezet, az épített közlekedési infrastruktúra, a kialakult kötöttpályás hálózat, mind sugallja az elektromos meghajtású járművek használatának bővítését. Az elektromos jármüvek térhódításának lehetôségét két irányban vizsgálja az Európai Unió által támogatott H2020-as ELIPTIC projekt. Az egyik irány a trolibusz vonalak bỏvítése, meghosszabbítása felsővezeték építése nélkül, az autóbusszal végzett szolgáltatási arány kárára. A másik irány a meglévő infrastruktúrára épülő multifunkcionális elektromos töltő hálózat kiépítése.
\end{abstract}

\begin{abstract}
In our urbanizing world has always been an important task the design and implementation of an efficient, economical, sustainable local transport system. Under the sustainability Today, almost everyone understands the environmentally friendly use of energy-efficient solutions, which are alternatives to private transport electric public transport, cycling, walking, car-sharing and e-car was driving the generally accepted approach. Due to increasing population and changes of lifestyle, expands the number of individual trips and ever more complex to offer a solution that meets the man of our time. In Szeged, the settlement structure, the built transport infrastructure, the track-developed network, all suggest the expansion of the use of electric vehicles. The possibility of penetration of electric vehicles examines in two directions the H2020's ELIPTIC project funded by the European Union. One of the directions is the expansion, extension of trolleybus lines without the overhead construction reducing the rate by coach and bus services. The other direction to build a multifunctional electric charger network based on the existing infrastructure.
\end{abstract}

Kulcsszavak: fenntartható helyi közlekedés, közösségi közlekedés, elektromos infrastruktúra, multifunkcionális elektromos töltőhálózat

Keywords: sustainable local transport, public transport, electrical infrastructure, multifunctional electric charging network

\section{Az ELIPTIC és Szeged elektromos közösségi közlekedése}

Az ELIPTIC (ELectrIfication of Public Transport In Cities) projekt (1. ábra) elsődleges célja megtalálni a lehetőségeket a helyi közösségi közlekedés terén az elektromos szolgáltatás bövítéséhez. Ennek a célnak az eredményes eléréséhez a nemzetközi konzorciumban 33 tag 3 évre 6 millió EUR kereten belül kutat, tesztel, vizsgál és egyeztet 2015 óta. A tagok között neves egyetemek, közlekedési operátorok, közlekedésszervezők, jármü és hálózati rendszerek gyártói és egyéb szervezetek, intézetek müködnek együtt nyolc országból. A kutatási témakörökből kettő érinti Szeged közlekedését, a Szegedi Közlekedési Kft. és a Szegedi Tudományegyetem Mérnöki Kar közremüködésével. 


\section{1. ábra: ELIPTIC projekt hivatalos logó}
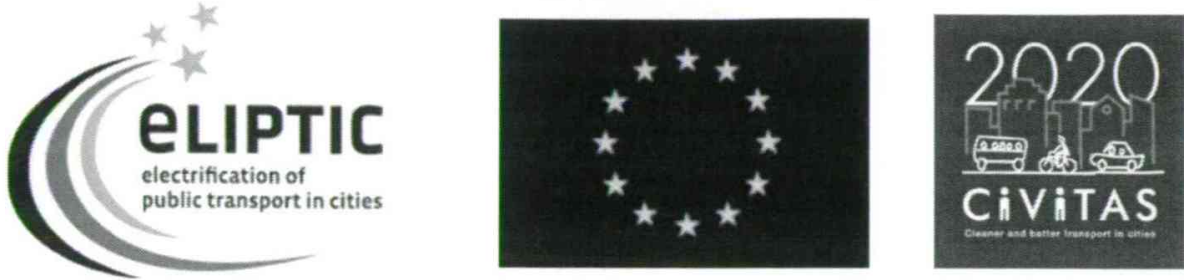

This project has received funding from the European Union's Horizon 2020 research and innovation programme under grant agreement No 636012.

Forrás: http://www.eliptic-project.eu/ (2017)

Szeged, elég kedvező helyzetben van az elektromos közösségi közlekedés jelenléte és részaránya szempontjából. 2014-ben fejeződött be az uniós támogatással megvalósult nagyprojekt, mely keretében közel 30 milliárd forintért bővült és újult meg az elektromos közösségi közlekedés, ami az Önkormányzat szolgáltatásmegrendelési elképzeléseinek is köszönhetően a mért utazásszámok alapján a villamosok és trolibuszok térnyeréséhez vezetett az autóbuszok csökkenésével szemben. Ezt a képet csak a teljes utazások arányában mért modal split változása és tendenciái árnyalja, amit az utazási értékcikkek értékesítésében is elég egyértelmüen felismerhetünk (2.-3. ábrák).

Az igaz ugyan, hogy a városi utazási szokások inkább a környezetbarát kerékpáros közlekedés és a gyaloglás irányában bővültek az elmúlt években, de a domináns elvek és a nemzetközi elképzelések szerint fontos lenne, hogy az elektromos közlekedés egyre nagyobb részarányra tegyen szert.

2. ábra: Szeged helyi közösségi közlekedés utasszámainak alakulása (1993-2015)

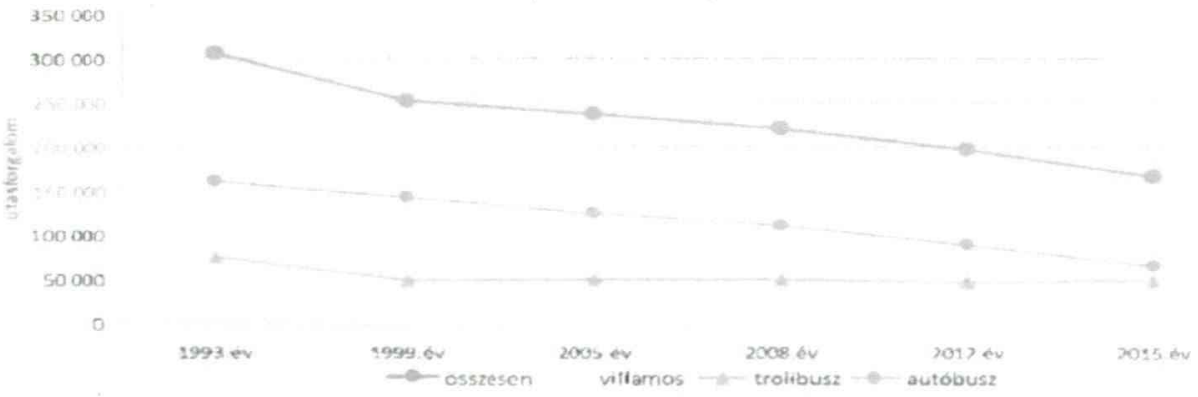

Forrás: One Planet Mérnöki Iroda Kft. adatai alapján Szegedi Közlekedési Kft. Üzleti terv (2016) 
3. ábra: Szeged helyi értékesítés 2006-2016 között

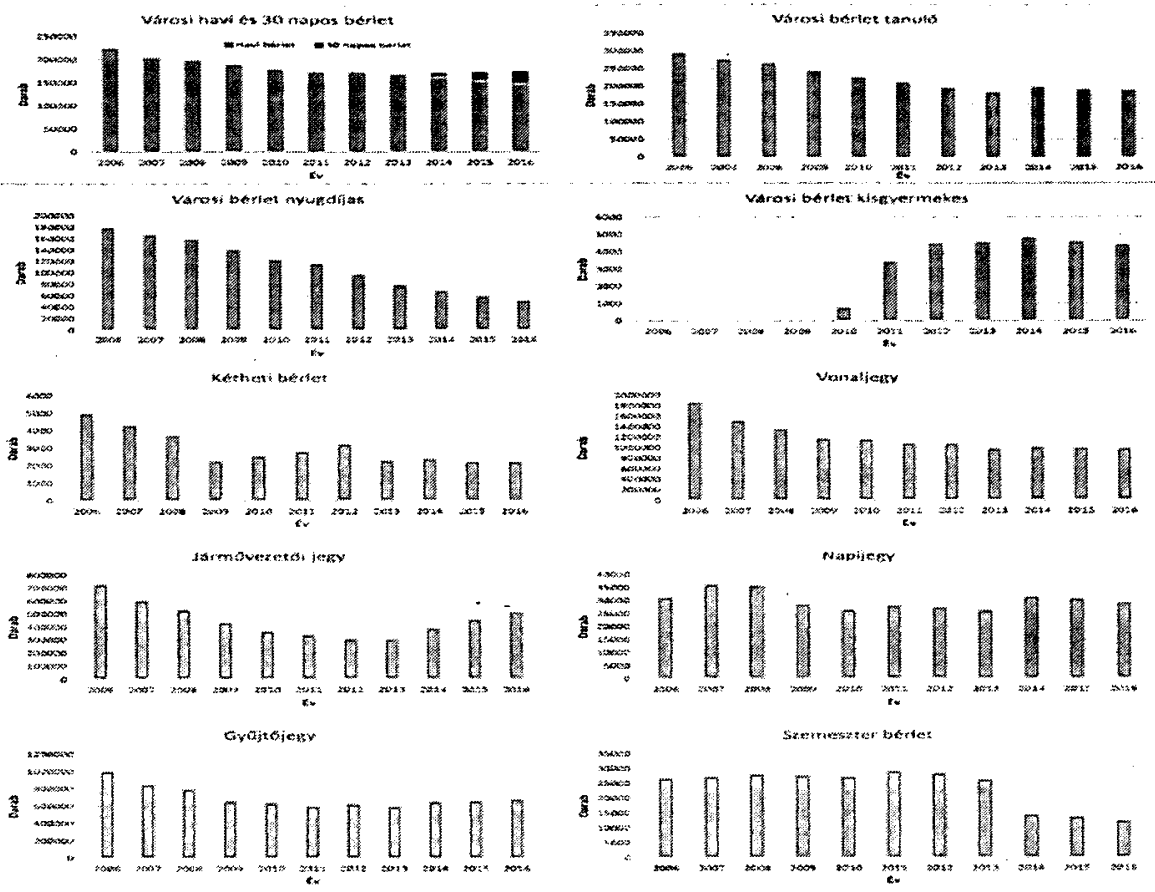

Forrás: Szegedi Közlekedési Kft 2016. évi beszámolója (2017)

\section{Az elektromos hajtás szerepe a jármúfejlesztésben és lehetőségei Szegeden}

Az elektromos hajtás története az önjáró jármüvekkel majdnem egyidös és akár már 1830-tól számolhatunk velük. Már az 1880-as években müködtek a fékezéskor egyébként elvesztegetett mozgási energiát hasznosítani képes jármủvek, melyek közül az elektromos meghajtás eleddig a legjobb (www.alternativenergia.hu). Talán majd az egymással és a közlekedési infrastruktúra elemeivel kommunikáló „önvezetö" jármüvek teljeskörü térhódítása esetében el lehet érni, hogy a jármüveknek nem kell többször fékezniük két végpont között, nem lesz mód rekuperálni a jármü kinetikus energiáját. Napjainkban még azonban, főként városi közlekedésben a rekuperáció forrását adó fékezési energia megközelítheti a gyorsításokra fordított energia szintjét, szakaszhosszaktól és átlagsebességtől függöen elérheti a ráfordított összenergia $80-90 \%$-át is. A nagyvárosi közösségi közlekedés pedig a legjellemzőbb színtere az ilyen típusú üzemeltetésnek. A menetrendi idők, megállók, kereszteződések kikényszerítik a gyorsításokat és lassításokat, ráadásul a teljes munkaidőn belül, jármủvenként akár napi $200 \mathrm{~km}$-en át. Jogosan merül fel a kérdés, hogy amíg a Toyota már húsz éve gyárt piacra rekuperációra képes hibrid személyautót, az ebben elméletileg jóval érdekeltebb tömegközlekedésnél miért csak az elmúlt évtizedben indultak újra próbálkozások, illetve az aktív fejlesztések alig 5 éve. 
A villamosoknál a teljesítményelektronika megjelenésével már a 90-es évektől elérhető volt a technológia és az eszköz, pl. Szegeden is a Tatra T6A2 (4. ábra), de a hálózati feltételek, egyéb tényezők miatt a keletkező megtakarítások és a kapcsolódó eredmények nem érték el sem a döntéshozók, sem a nagyközönség ingerküszöbét.

\section{4. ábra: Rekuperációra képes Tatra T6A2}

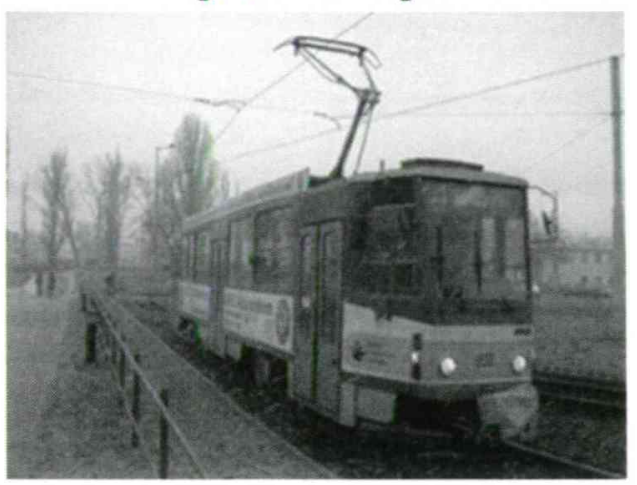

Forrás: http://szkt.hu/jarmuveink\#villamosok (2016)

Adott táphálózatról működtetett, főként kötöttpályás jármüpark esetén különösen hatékony lehet a napjainkban szintén egyre erősödő automata, vagy a már említett önvezető üzemmód. Amennyiben a hálózaton közlekedő jármủveket összehangoltan lassítjuk és gyorsítjuk, akkor a rekuperált energiát maximálisan hasznosítani lehet, szinte csak az átalakítási és a tranzit veszteségekkel kell számolni. Ehhez azonban nagyon okos és megbízható rendszerre és hajtásvezérlésre van szükség, ami inkább a nagy tőkével rendelkező gyártóknál jelenik meg először, mint például a Volvo, Mercedes, BMW flotta vezérlési elképzelései is mutatják, amelyek figyelembe veszik a forgalomban részt vevő többi szereplő helyzetét, sebességét, várható célját, az utak vízszintes és függőleges pályavonalát, minőségét, zsúfoltágát és a legtöbb, mozgást befolyásoló tényezőt. Ebben a formában azonban számunkra még elég távolinak tünik ez a megoldás.

Az elektromos hajtás mindezeken felül további jelentős pozitívumokkal bír, mert a jármüben növeli a fékrendszer élettartamát, a helyi emissziót, benne a zajkibocsátást is, minimalizálja. Kiemelkedő hatásfok értéke miatt a járművön mérhető fajlagos fogyasztás a belsőégésủ motorokénak alig a harmada-negyede, jelenleg még nem terheli az áramot olyan többlet adóterhek, mint a fosszilis energiahordozókat, így olcsóbban ,tankolható”.

Természetesen a negatívumoktól sem mentes az elektromos hajtás, igaz ezt a mainstream média kevésbé emlegeti. Maguk a járművek a tradicionális hajtásúakhoz képest legalább kétszeres árral bírnak, a kötöttpálya esetén az energiaellátás, a hálózati elemek építési és fenntartási költségei, műszaki és forgalmi zavarérzékenysége és annak kezelése, az üzemeltetők számára már drágábbá teszik a fajlagos költségeket a legmodernebb dízelüzemủ buszoknál is közel $50 \%$-kal. A 
nem kötöttpályásoknál az energiatárolás okozott komoly fejtörést az elektromos autózás egész történetében, ami az 1930-as években részben az elektromos személyautók kihalásához is vezetett, mert nehéz volt az akkumulátor, rövid a hatótáv és hosszú a töltési idő. Napjaink tömegközlekedési járműveiben ez az akkumulátorok helyigénye és tömege miatti kisebb utaskapacitásban, a töltési feltételek biztosításának szükségességében, az akkumulátorok valós töltöttségi állapotának, az ezzel részben összefüggő várható élettartamának bizonytalanságában és a várható pótlási költség költségeiben jelent problémát.

\subsection{Szeged trolibusz hálózatának bővítési lehetőségei}

Szegeden hat trolibuszvonal, szám szerint az 5, 7, 8, 9, 10, 19-es vonalak összesen 37,654 km hosszú felsővezetékpárral kerül kiszolgálásra (5. ábra).

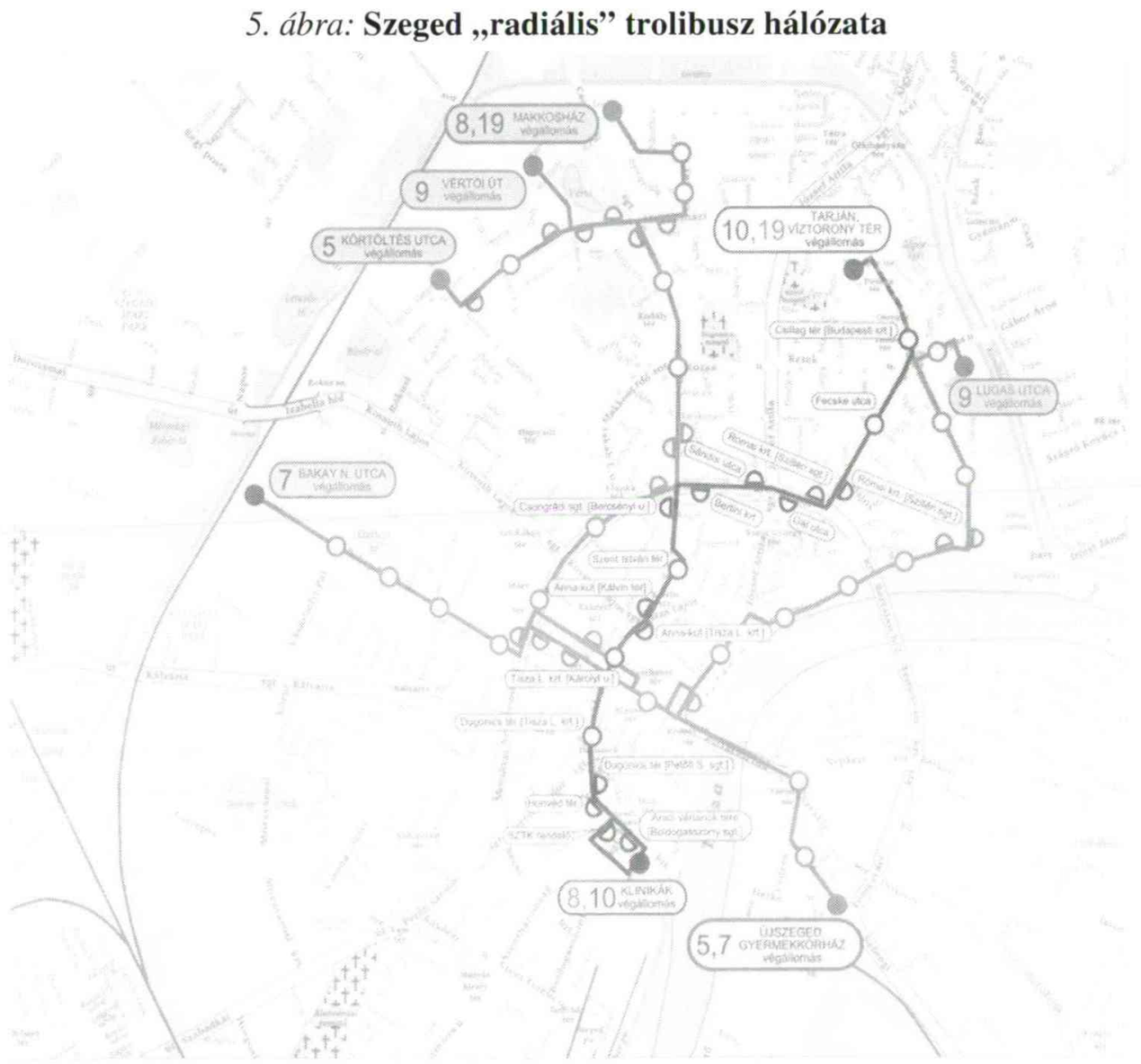

Forrás: Szegedi Közlekedési Kft. (2015)

A menetrendi szolgáltatáshoz 2016-ban 23 szóló és 41 csuklós trolibusza volt a Szegedi közlekedési Kft-nek, ami alig 67\%-os rendelkezésre állást jelent, azaz jármú fronton lenne bevethető tartalékállomány a nagyobb szolgáltatási teljesítményhez 
(SZKT honlap). A legújabb 13 db Ikarus-SKODA TR187-2 csuklós akkumulátoros hibrid jármủ képes 7 km távon táphálózattól függetlenül, autonóm üzemmódban közlekedni, ami képességük egyenlöre csak a zavarérzékenység csökkentését biztosítja. A hálózat bővítését a felsővezeték építési költségei és a kialakítás helyigénye jelentősen korlátozzák. Sokkal egyszerübb lenne a meglévő vonalak olyan jellegủ meghosszabbítása, ahol az infrastruktúra változtatása nélkül a hibrid trolibuszok hatótávolságát kihasználva lehetne bővülni. Napjaink környezetvédelmi elképzelései az autóbuszos szolgáltatás helyett szívesebben is látnák a tisztán elektromos üzemü járműveket. Ez a helyi emissziós adatokra jótékony hatással lenne, igaz a legutóbbi információk szerint a járművektől csak elég kis mértékben függ például a szmog kialakulása, ráadásul nem is elsősorban az emissziójuktól, hanem a mozgásuk során felkavart levegőtől, ami az elektromos járműveknél a mozgásdinamikájuk miatt elvileg magasabb is lesz.

Szeged közösségi közlekedési hálózatára tekintve (6. ábra) láthatjuk, hogy jelentősek az átfedések, párhuzamosságok a kékszínủ autóbusz- és a piros trolibuszvonalak között, ezért szinte magától értetődik a kiváltás lehetőségeinek keresése. Mivel ez az ábra 2013-as, ezért már meg is valósultak bizonyos módosítások az elektromos nagyprojekt keretén belül, de ezek felsővezeték építéssel történtek.

\section{6. ábra: Szeged közösségi közlekedési hálózata}

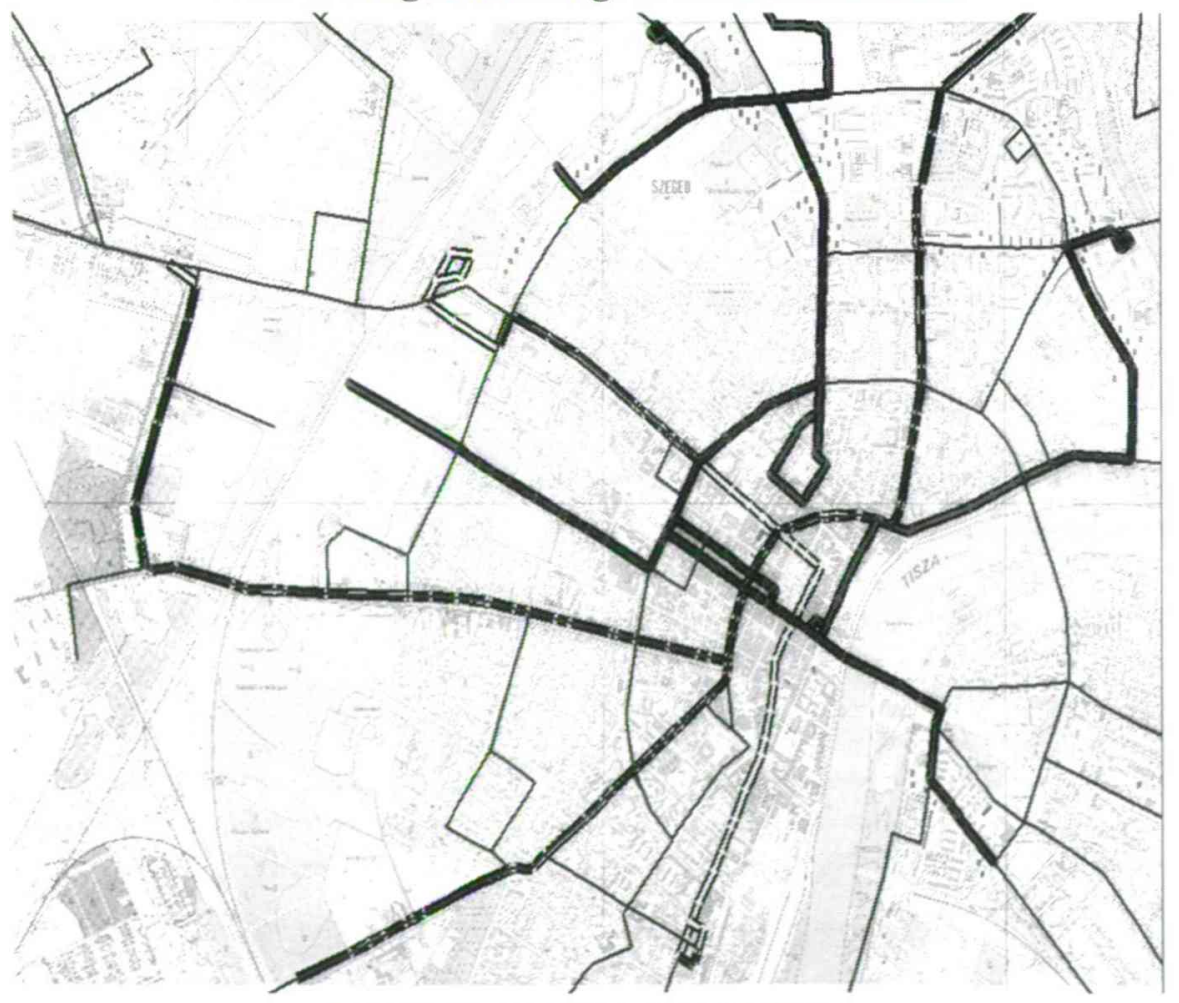

Forrás: Szegedi Közlekedési Kft. (2013) 
A további kiváltásoknak komoly korlátjai vannak. Egyrészt a Közszolgáltatási Szerződés a buszos szolgáltatóval, másrészt a Szegedi Közlekedési Kft. korlátozott számú önjáróképes jármüparkja, harmadrészt a fajlagos költségek közötti különbség, negyedrészt az akkumulátorok várható élettartamával kapcsolatos bizonytalanság.

Az ELIPTIC projekt keretében végzett utaskikérdezések azt mutatják, hogy a lakosság többségében örülne az elektromos jármüvek térnyerésének (Gál-Tóth, 2016), igaz ez az eredmény is támadható, mert az új, modern önjáró trolibuszok, ha nem is szándékosan, a régebbi Ikarusokkal kerültek összevetésre és nem az új Scaniakkal. Mindenesetre érdemes egy részletes elemzést végezni az ilyen irányú fejlesztés rövid- és hosszútávú lehetséges következményeinek kiértékeléséhez, amit az ELIPTIC projekt célul tüzött ki.

2.2. A Szegedi Közlekedési Kft. elektromos hálózatának lehetséges hasznosítása multifunkcionális töltőhálózat kialakításához

A városi közlekedés többi szereplöi az elektromos eszközök széles választékából meríthetnek, az elektromos roller, kerékpár, Segway, tisztán elektromos hajtású autó, hibrid és plug-in hibrid elektromos autók közül mind, mondhatni elérhető közelségben van. Ahhoz, hogy ezek jobban elterjedjenek, sokat segíthet egy elérhető töltőhálózat felállítása, ami akár a már meglévő infrastruktúra hasznosítását is hatékonyabbá teheti. Legalábbis ez volt az alapötlet az ELIPTIC projekt megfogalmazásakor.

A szegedi 29,5 milliárd forintos elektromos nagyprojekt keretén belül a villamos és trolibusz hálózat felújítása és bővítése mellett a várható többletteljesítmény biztonságos ellátása érdekében az eredeti négy áramátalakító felújításán túl további hat keruilt a rendszerbe (7. ábra), jelentős tartalékot sugallva, melyből esetleg érdemes lehet a tisztább közlekedés elősegítése érdekében lehetőséget teremteni napközben kisebb-nagyobb energiapótló töltésekre a többi elektromos hajtású eszközzel közlekedőnek. Ehhez a Szegedi Közlekedési Kft. egyenáramú 600 voltos hálózatából az arra érdemes helyeken multifunkcionális töltőberendezések alkalmazásának a lehetőségét vizsgálja, vizsgálta a projekt.

A múlteset itt sajnos helyénvaló, mert annyi és olyan szintü korlát merült fel az elemzés során, hogy nagyon korán be kellett látni, hogỳ életképesebb a városi elektromos hálózatra építeni az ilyen töltési hálózat tervezését. Jogi, gazdasági, technikai kérdések sora vár megoldásra még ebben az esetben is.

\section{Az elektromos jármüvek térnyerésének lehetöségei és lehetséges következményei}

Az ELIPTIC projekt csak két apró részletét célozta meg az elektromos meghajtású jármüvek lehetséges jövöképének. Ez a két csipet nem jelentene érdemi változást az elektromos jármúvek arányában, mégis rámutat, hogy mennyi kérdést, mennyi oldalról kell megvizsgálni mielőtt döntés születne. 


\section{7. ábra: Az SZKT 600 V-os egyenáramú hálózata}

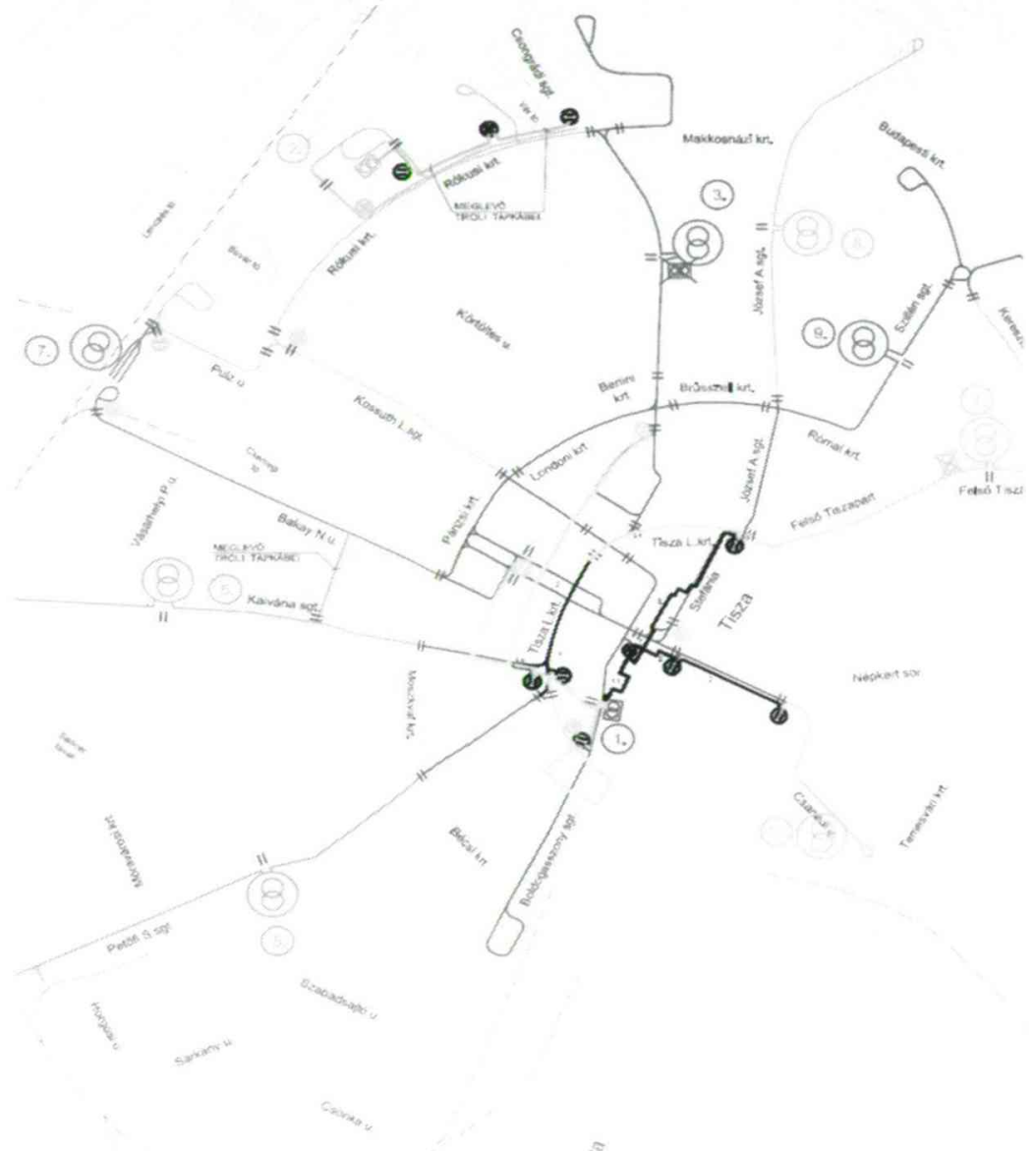

Forrás: Szegedi Közlekedési Kft. (2015)

Külön érdemes vizsgálni a helyi lehetöségeket és következményeket, de ezek kialakulásának mértéke nem független a kormányzati és a nemzetközi feltételek, szabályozók, szubvenciók alakulásának hatásaitól.

\subsection{Helyi szintủ lehetöségek és következmények}

A 2016-ban bevezetett zöld rendszám és a hozzá kapcsolódó beszerzési támogatás és az egyes városokban meghirdetett parkolási-, adó- és más kedvezmények, a még elérhető ingyenes töltési lehetőségek akár tömeges elterjedéshez is vezethettek volna, ahogy azzal a Jedlik Ányos terv számolt. Ez nem történt meg. Szegeden nem hirdettek az általánosnál több kedvezményt, ezért nem fenyegetik a parkolási bevételeket az elektromos autók, ami egyébként a rendelkezésre álló 2216 db fizető parkolóhely 2016-os 901 MFt-os bevételéből (SZKT Üzleti jelentés 2016. 6. old.) komoly kiesés lenne, mivel egyetlen jó kihasználtságú parkoló e-autós elfoglalása 
éves szinten 1 MFt kiesést is jelenthet. A töltőhelyek kialakítása is pénzbe kerül, üzemeltetésük sem ingyenes, a villámtöltők esetében pedig a szükséges nagy, 150$200 \mathrm{~kW}$ teljesítmény miatt nem is lehet bárhol telepíteni.

A közösségi közlekedési jármüpark bővítése elektromos irányban hasznos lenne a gördülő állomány átlagos életkora, az arculat, esetleges utasvonzó hatása, környezetvédelmi paraméterei miatt, azonban nincs forrás a beszerzésre és mivel a fajlagos költségek az új jármüvek esetében magasabbak a régiekénél, ezért az üzemeltetésükre sem jutna fedezet.

\subsection{Országos szintü lehetőségek és következmények}

Országos szinten, ha csak minden harmadik autó elektromos lesz és azok napi 30 $\mathrm{km}$-es futásteljesítménye alatt elfogyasztott $4-5 \mathrm{kWh}$ energiáját éjjelente a tulajdonosok 5-6 óra alatt akarják feltölteni, akkor ez 1000 MW teljesítményt igényel. Ehhez járul még hozzá a közösségi közlekedési, a városi logisztikai, rendészeti, közszolgálati, közintézményi stb. jármúvek energiaszükséglete, ami szintén elérheti, vagy akár meg is haladhatja a következő 1000 MW-ot. Mind ezek mellett a magánfelhasználóknál megjelenő többlet energiaigény kiszolgálása miatt nagy a valószínüsége, hogy jelentős költségü hálózati fejlesztésre is szükség lesz. Ugyanakkor, amennyiben nem változik a hazai energiamix, akkor a fajlagos emisszió alig lesz jobb, mint egy átlagos EURO-5, 6-os jármüpark esetén.

\section{Záró gondolatok}

Szegeden az elektromos hajtású jármüvek már most is jelentős szerepet töltenek be a közlekedésben. A legutóbbi felmérések szerint a közösségi közlekedésben a napi utazások több mint 60\%-át teljesítik (2.ábra), ami elvileg az összes utazásból is $21 \%$ körüli arány (SZKT Üzleti jelentés 2015. 9-10. old.). Ez már most is sokba kerül a város költségvetésének és a fejlesztése további komoly forrásokat igényel.

$\mathrm{Az}$ egyéni közlekedés terén Szeged város egyelöre nem ad speciális kedvezményeket, mint ingyenes parkolási lehetőség, buszsáv használat, az elektromos jármüvek terjedését a központi szabályozók támogatják korlátozott mértékben és ideig, mely határidőt egyelöre nem tervezik meghosszabbítani, a szubvenciós alap nem töltődik fel és nem indul újra.

Norvégia, Hollandia döntött az elektromos jármüvek terjesztése mellett, ugyanakkor a legfrissebb hírek szerint Németországban a lakosság nem kíván élni a szubvencióval és nem vásárol elektromos autókat a tervezett mennyiségben.

Magyarország jelenlegi energiamixe alapján az elektromos hajtás nem is olyan környezetbarát az emisszió szerint. Komolyabb mennyiségü jármü töltését csak kiegészítő erőmükapacitással, vagy a most is magas, $30 \%$ feletti importarány (MAVIR, 2017) jelentős növelésével lehetne biztosítani.

Az autonóm üzemü elektromos hajtású jármüvek történelmében már volt egy komoly kudarc, föként az energiaforrás hiányosságai miatt és ezek a hiányosságok még most is visszaköszönnek.

Komolyan el kellene gondolkodni, hogy költség-haszon elven érdemes-e itthon foglalkozni a terjesztéssel, vagy jobb lenne esetleg türelmesen kivárni a fejlettebb, 
tökeerősebb államokban zajló folyamatok eredményeit minden elfogultság nélkül, hideg fejjel.

\section{Irodalomjegyzék}

ELIPTIC. <http://www.eliptic-project.eu/thematic-pillars> (2017.04.20.)

Gál J., Tóth I.T. Survey of Passengers' Travelling by Public Transportation in Szeged, Acta Technica Corviniensis, Tome IX (2016), Fascicule 3 (July-September) pp. 127-132. ISSN 2067-3809 $<$ http://acta.fih.upt.ro/pdf/2016-3/ACTA-2016-3-20.pdf> (2017.04.20.)

Az elektromos autózás rövid története. Forrás: chikansplanet.blog.hu. $<$ http://www.alternativenergia.hu/az-elektromos-autozas-rovid-tortenete/68280> (2017.04.20.)

Szegedi Közlekedési Kft. honlap. Rólunk, Jármüveink, Trolibuszok. <http://szkt.hu/> (2017.04.20.)

MAVIR, Adatpublikáció, Import-export energia szaldó részaránya, A teljes bruttó villamosenergiafelhasználás és az import-export energia szaldó részaránya 2016-2017 <http://www.mavir.hu/documents/10258/218197257/201703_Importreszarany_HU.pdf/cde6d 1 af-5 1ca-4450-8fbf-5eb1ca8da85c> (2017.04.20.) 